\title{
Length-weight relationship, breeding season, sex ratio, maturity and fecundity of the Nile catfish Synodontis schall (Bloch and Schneider, 1801) (Pisces: Mochokidae) in Lake Chamo, Ethiopia
}

\author{
Elias Dadebo \\ Hawassa University, College of Natural and Computational Sciences, Department of Biology, P. O. Box 05, Hawassa, \\ Ethiopia, E-mail: edadebo@yahoo.com, Tel. +251911750307.
}

\begin{abstract}
Length-weight relationship and some aspects of reproductive biology of the Nile catfish Synodontis schall (Bloch and Schneider, 1801) in Lake Chamo, Ethiopia were studied from fish sampled in each month during January to December 2010. The relationship between fork length (FL) and total weight of males $\left(\mathrm{TW}=0.020 \mathrm{FL}^{3.207}, \mathrm{R}^{2}=\right.$ $0.965, \mathrm{n}=277)$, females $\left(\mathrm{TW}=0.020 \mathrm{FL}^{3.248}, \mathrm{R}^{2}=0.976, \mathrm{n}=407\right)$ and the sexes combined $\left(\mathrm{TW}=0.020 \mathrm{FL}^{3.240}\right.$, $\mathrm{R}^{2}=971, \mathrm{n}=684$ ) were curvilinear and statistically significant (ANOVA, $P<0.05$ ). The proportion of breeding fish was high between May and September, during which time $46.8 \%-72.0 \%$ of the males and $41.3 \%-77.9 \%$ of the females had ripe gonads. Thus, the months with high proportions of breeding fish were considered as the breeding season of the fish. More number of females was caught in all size classes but sex ratios were significantly different from 1:1 in size classes 30.0- $34.9 \mathrm{~cm}$ FL and 35.0- $39.9 \mathrm{~cm}$ FL. The overall male to female sex ratio of 1:1.39 was also significantly different $\left(\chi^{2}=24.71, P<0.001\right)$ from the theoretical ratio of 1:1. Size at first maturity of males was $23.1 \mathrm{~cm}$ FL while that of females was $26.4 \mathrm{~cm}$ FL. Fecundity ranged from 3,500- 54,089 eggs with a mean of 21,017 eggs. The mean relative fecundity of $S$. schall was $76.1 \mathrm{eggs} \mathrm{g}^{-1}$ of body weight. The average number of eggs $\mathrm{g}^{-1}$ of ovary (preserved wet weight) ranged from 983 to 3,797 with a mean of 1,847 eggs $\mathrm{g}^{-1}$. The relationships between fecundity and fork length and fecundity and total weight were curvilinear while the relationship between fecundity and ovary weight was linear.
\end{abstract}

Key words: Breeding season, length-weight relationship, sex ratio, size at maturity, fecundity, S. schall, Lake Chamo

DOI: $\underline{\text { http://dx.doi.org/10.4314/ejst.v9i2.2 }}$

\section{INTRODUCTION}

The genus Synodontis, commonly referred to as squeaker or upside-down catfish is widely distributed in African freshwaters ranging from the Nile basin, Chad, Niger and much of the West African region (Paugy and Roberts, 1992). The genus has over 112 species (Daget et al., 1991) and some of the species are commercially important comprising up to $40 \%$ of the total landings by weight in some regions of Africa (Willoughby, 1974; Sanyanga, 1996). S. schall is the most tolerant species of the genus to adverse environmental conditions and it has the widest distribution in Africa (Lowe-McConnell, 1987). In Ethiopia, it is found in Lakes Abaya, Chamo, Turkana and Omo River in the south, Baro River and its tributaries in the west and in Wabe Shebele River in the southeast (Shibru Tedla, 1973; Paugy and Roberts, 1992; Golubtsov et al., 1995; Mulugeta Wakjira, 2016). S. schall does not have any direct commercial importance to the traditional fishery of Lake Chamo, apart from being used as bait to capture other piscivorous fish species.

\footnotetext{
(C) This is an Open Access article distributed under the terms of the Creative Commons Attribution License (http://creativecommons.org/licenses/CC BY4.0).
} 
However, it is ecologically important because it serves as the main prey of the commercially valuable catfish (Bagrus docmak, Forsskål) (Hailu Anja and Seyoum Mengistou, 2001). It is also among the prey fishes of the most valued piscivore, the Nile perch (Lates niloticus) in this lake (Elias Dadebo, 2002). S. schall is one of the most abundant fish in both littoral and pelagic regions of the lake. According to Elias Dadebo et al. (2012) the fish picks scales from the bodies of other fish using comb-like bony structures found on the marginal part of its mouth. The local fishermen consider the species as a nuisance since it entangles to their gill nets by its long and serrated spiny fin rays making it very difficult to remove from the gillnets.

Several workers have studied the reproductive biology of $S$. schall in some other African water bodies such as breeding season (Halim and Guma'a, 1989; Lalèyè et al., 2006), size at first maturity (Willoughby, 1979; Albaret, 1982, Ofori-Danson, 1992) and fecundity (Nawar, 1959; Halim and Guma'a, 1989; Ofori-Danson, 1992). However, no published work is available on the reproductive biology of $S$. schall in Lake Chamo. The aim of this work was to study length-weight relationship and some aspects of reproductive biology of the fish in Lake Chamo. Since the fish is not exploited at all, developing its fishery is important and thus, scientific knowledge is required for proper utilization and management of the stock.

\section{MATERIALS AND METHODS}

\section{Description of the study area}

Lake Chamo (Latitude: $5^{\circ} 42^{\prime}-5^{\circ} 58^{\prime} \mathrm{N}$; Longitude: $37^{\circ} 27^{\prime}-37^{\circ} 38^{\prime}$ E) has a surface area of approximately $551 \mathrm{~km}^{2}$, a maximum depth of $16 \mathrm{~m}$ and lies at an altitude of 1,108 $\mathrm{m}$ (Figure 1)
(Amha Belay and Wood, 1982). The lake lies to the east of the Precambrian block of the Amaro Mountains within less intensely faulted basin (Mohr, 1962). The surrounding region receives two rainy seasons per year, March- May (heavy rains) and September-October (little rains). The main affluent of the lake is Kulfo River, which inflows at the north end of the lake and the less important feeders are Sile and Sago Rivers entering from the west (Figure 1). During the past three decades, the water level of the lake has declined considerably and this has resulted in significant shrinkage of the lake's surface area (personal observation).

The ichthyofauna of Lake Chamo, and also that of Lake Abaya is Soudanian (Beadle, 1981). The fish species are more diverse than the other rift valley lakes of the country, as a result of the possible northward migration of the Soudanian species when the lake was connected with the Nile system 7,000 years ago (Golubtsov and Redeat Habteselassie, 2010). There are 18 fish species in Lake Chamo and the inflowing rivers belonging to 9 families and 12 genera. The landings of the commercial fishery are mainly composed of Oreochromis niloticus (L.), Labeo horie (Heckel), Lates niloticus (L.), Bagrus docmak (Forsskål) and Clarias gariepinus (Burchell). The potential production of the lake was estimated to be 3,340 tons/year whereas the actual landings from the above commercial species have not exceeded 2,500 tons/year (Reyntjens et al., 1998).

\section{Sampling}

Monthly fish samples were obtained from three sites between January and December 2010 using a fleet of gill nets $(60 \mathrm{~mm}, 80 \mathrm{~mm}$ and $100 \mathrm{~mm}$ stretched mesh sizes) in the pelagic area of the lake 


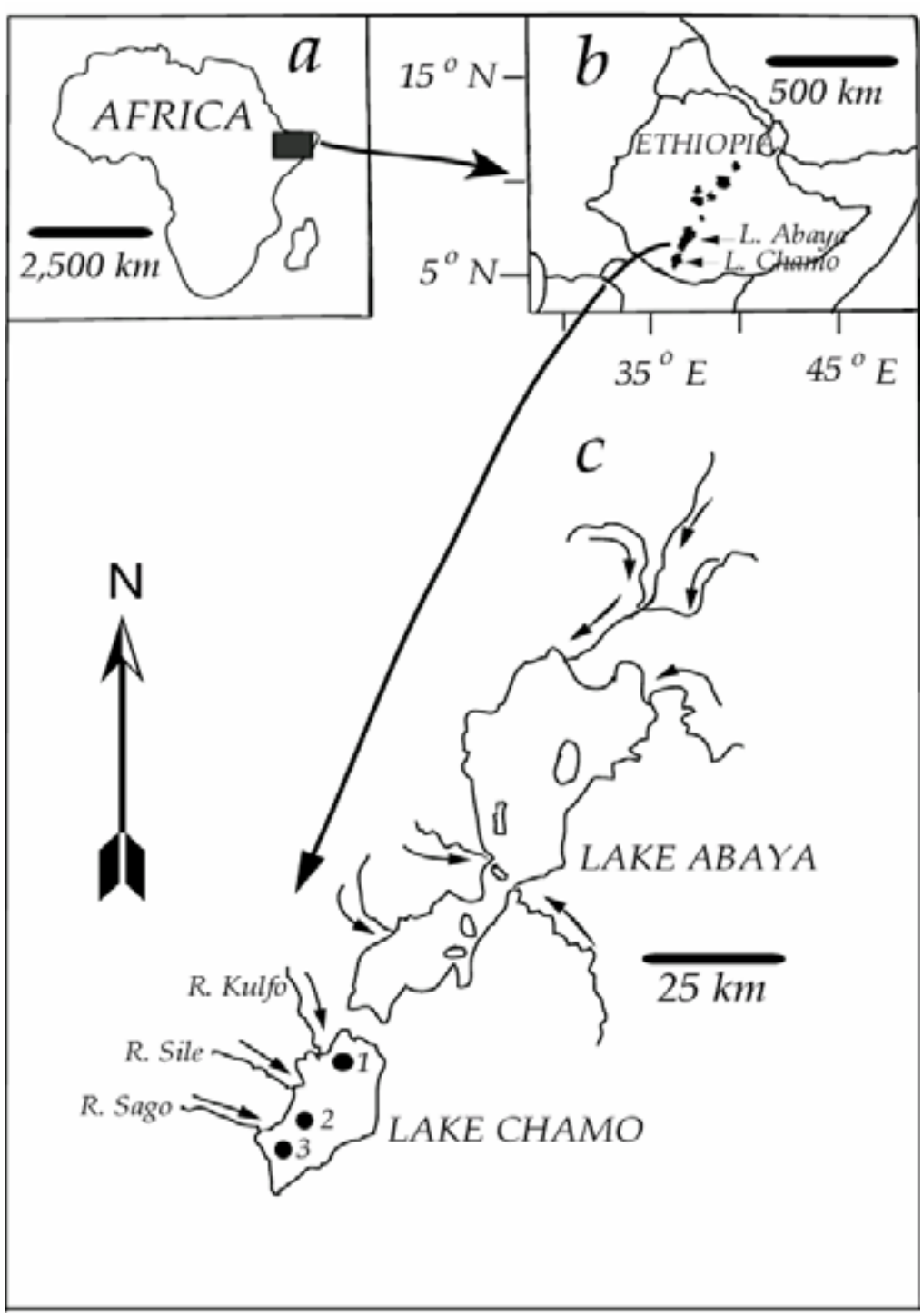

Figure1. Map of Africa with the relative position of the Horn of Africa highlighted (a), map of Ethiopia with the relative position of the Ethiopian rift valley lakes indicated (b) and map of Lakes Abaya and Chamo with the sampling stations in Lake Chamo indicated (c) (1- Deset, 2Bedena, and 3-Bole). Arrows indicate direction of river flow.

(Figure 1c). The gill nets were usually set $3-5 \mathrm{~km}$ from the shoreline of the lake late in the afternoon at around $5.00 \mathrm{pm}$ and lifted early the next morning around 6.00 am local time. Beach seine ( $25 \times 4 \mathrm{~m})$ and small hook and line gear (the hooks were $4 \mathrm{~cm}$ in length) were also used to capture juvenile fish in the shallow littoral areas. Fork lengths of all fish were measured to the nearest millimeter and total weights were taken to the nearest gram.
The sex and maturity stage of each fish were determined by visual examination of the gonads using a five-point maturity scale. This maturity scale describes the development of gonads based on their sizes and the space they occupy in the body cavity of fish (Holden and Raitt, 1974). Accordingly, gonad maturity was categorized as immature (I), recovering spent or developing virgin (II), ripening (III), ripe (IV) and spent (V). Ripe ovaries were removed, weighed to the nearest 0.1 
$\mathrm{g}$, and preserved in Gilson's fluid. In order to assist penetration by the preservative, the ovaries were split longitudinally and turned inside out (Bagenal and Braum, 1978).

The length-weight relationship was determined using the formula:

$\mathrm{W}=\mathrm{aL}{ }^{\mathrm{b}}$ (Nielsen and Johnson, 1983).

$$
\begin{array}{ll}
\text { Where, } & \mathrm{W}=\text { total fish weight }(\mathrm{g}) \\
\mathrm{L}=\text { total length of fish }(\mathrm{cm}) \\
\\
\mathrm{a} \text { and } \mathrm{b}=\text { parameters }
\end{array}
$$

\section{Breeding season}

The breeding season was estimated from the percentages of fish with ripe gonads taken each month. Since fish with ripe gonads were found all year round, breeding season was taken as the period of the year when relatively higher proportions of fish were in breeding condition.

\section{Sex ratio}

Male to female sex ratio was calculated as the numbers of each sex divided by the number of males. This was done by sampling months, fish length classes and for the total sample. A chi-square test was then used to determine if the sex ratios varied between months and size classes and total sample (Frank and Althoen, 1994).

\section{Size at first sexual maturity}

The percentages of male and female $S$. schall having gonad stages III - V (Holden and Raitt, 1974) were plotted against length for each sex using data from the breeding season (May September 2010). Average size at first maturity $\left(\mathrm{L}_{\mathrm{m} 50}\right)$ has been defined as the length at which $50 \%$ of individuals reach sexual maturity (Willoughby and Tweddle, 1978). Thus, $\mathrm{L}_{\mathrm{m} 50}$ of $S$. schall was estimated from the relationship between the percentages of mature fish (P) of length class (L) as described by the logistic function (Echeverria, 1987):

$\mathrm{P}=\mathrm{e}^{(\alpha+\beta)} /\left(1+\mathrm{e}^{-(\alpha+\beta \mathrm{L})}\right)$

and the value of $\mathrm{L}_{\mathrm{m} 50}$ was estimated from the expression:

$\mathrm{L}_{\mathrm{m} 50}=-\alpha / \beta$

The individuals of fish used in the estimation of $\mathrm{L}_{\mathrm{m} 50}$ were collected during the spawning season of the fish as found in this study, i.e. May - September (see Results section). The proportion of mature fish for each 2-cm length class was calculated separately for males and females and $\alpha$ and $\beta$ were estimated using Marquardt's (1963) algorithm of non-linear least squares regression.

\section{Fecundity}

Fecundity was estimated gravimetrically (Snyder, 1983). Thus, for each fish, the number of eggs in three sub-samples of eggs each weighing $1 \mathrm{~g}$, was determined from which average number of eggs per gram of ovary was calculated. The weight of all the eggs in ovaries was also calculated. Fecundity as total number of eggs per ovary $(\mathrm{F})$ was then estimated for each fish as in:

$$
\mathrm{F}=\mathrm{W}^{*} \mathrm{n} / \mathrm{W}
$$

Where, $W=$ Weight of all eggs $\mathrm{n}=$ Average number of eggs per gram $\mathrm{w}=$ Weight of sub samples of eggs

$$
(=1 \mathrm{~g})
$$

In addition, relative fecundity as number of eggs per ovary weight as well as per total body weight was also calculated. 


\section{Statistical analysis}

Chi-square test was used to compare sex ratios of the fish at different size classes and seasons of the year. Length-weight relationship and relationships between fecundity $(F)$ and some morphometric measurements (fork length, total weight and ovary weight) were estimated using least squares regression. Logistic function was used to estimate $\mathrm{L}_{\mathrm{m} 50}$ from the relationship between the percentages of mature fish at different size classes.

\section{RESULTS}

\section{Length-weight relationship}

The relationship between fork length and total weight of $S$. schall in Lake Chamo was curvilinear and statistically significant $\left(\mathrm{R}^{2}=0.971, \mathrm{p}<0.001\right)$ (Figure 2). The regression equations for data of males, females and combined for the sexes were:

Males: $\mathrm{TW}=0.020 \mathrm{FL}^{3.207}, \mathrm{R}^{2}=0.965, \mathrm{n}=$ 277 (Figure 2a)

Females: $\mathrm{TW}=0.020 \mathrm{FL}^{3.248}, \mathrm{R}^{2}=0.976, \mathrm{n}$ $=407$ (Figure $2 \mathrm{~b}$ )

Males and females combined: $\mathrm{TW}=$ $0.020 \mathrm{FL}^{3.240}, \mathrm{R}^{2}=971, \mathrm{n}=684$ (Figure 2c)

\section{Breeding season}

Even though some ripe fish were caught throughout the year, the proportion of fish with ripe gonads was high between May and September, during which time $46.8 \%-72.0 \%$ of the males and $41.3 \%-77.9 \%$ of the females had ripe gonads (Figure 3 ). The proportions of fish with ripe gonads were relatively low from January to April when $3.5-21.9 \%$ of the males and $5.8-26.6 \%$ of the females had ripe gonads (Figure $3)$. The proportions of fish with ripe gonads were also low during the months of October - December when $3.4-13.7 \%$ of the males and $3.1-11.19 \%$ of the females had ripe gonads (Figure 3). Therefore, $S$. schall in Lake Chamo breeds intensively during May- September with some breeding activity at other times of the year. Intensive breeding activity coincided with the increase in the amount of precipitation and subsequent water level rise.

\section{Sex ratio}

From the total number of 684 fish samples, 277 $(40.5 \%)$ were males while the remaining 407 $(59.5 \%)$ were females. The males ranged in size from $8.5 \mathrm{~cm}-38.0 \mathrm{~cm}$ FL and $13.4 \mathrm{~g}-1,080 \mathrm{~g}$ while the females ranged in size from $9.4 \mathrm{~cm}$ $38.2 \mathrm{~cm} \mathrm{FL}$ and $14.9 \mathrm{~g}-1,170 \mathrm{~g}$. The average length and weight of the males were $27.1 \mathrm{~cm}$ and $414.3 \mathrm{~g}$, respectively. The average length and weight of the females were $28.4 \mathrm{~cm}$ and 489.1 $\mathrm{g}$, respectively. More number of females was caught in all size classes, but the sex ratios were significantly different from unity only in fish above $29.9 \mathrm{~cm}$ (Table 1). The overall sex ratio was also significantly different from the theoretical 1:1 ratio $\left(\chi^{2}=24.71, p<0.001\right)$ (Table 1$)$. Significantly more females were caught in February $\left(\chi^{2}=4.20\right.$, $\mathrm{p}<0.05)$ and October $\left(\chi^{2}=5.73, \mathrm{p}<0.05\right)$ but the ratio was not significantly different from 1:1 in the other months (Table 2).

\section{Length at first maturity}

The length at which $50 \%$ of the males first reached maturity was $23.1 \mathrm{~cm}$, while that of the females 

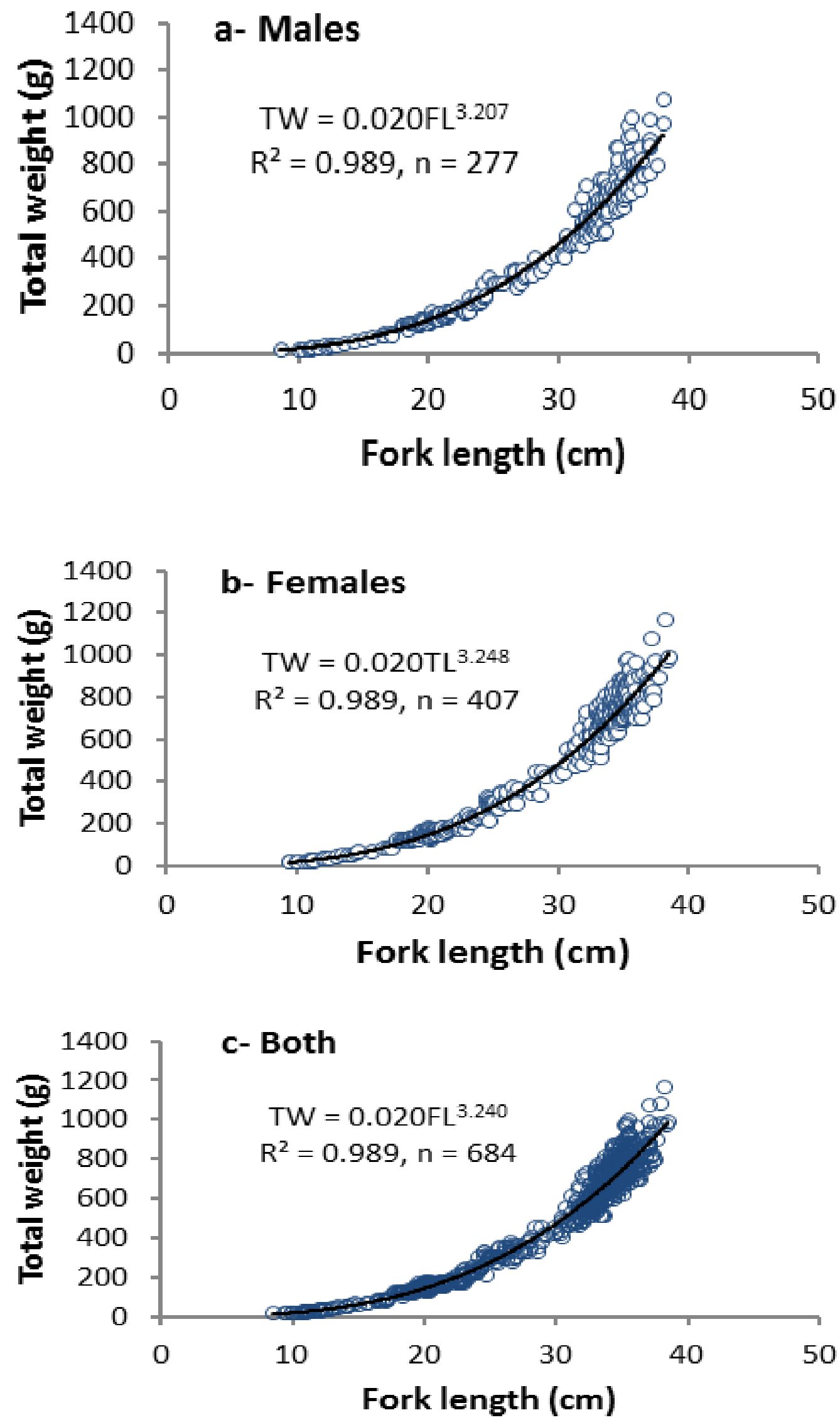

Figure 2. Length-weight relationship of S. schall from Lake Chamo, (a) males, (b) females and (c) males and females combined. 


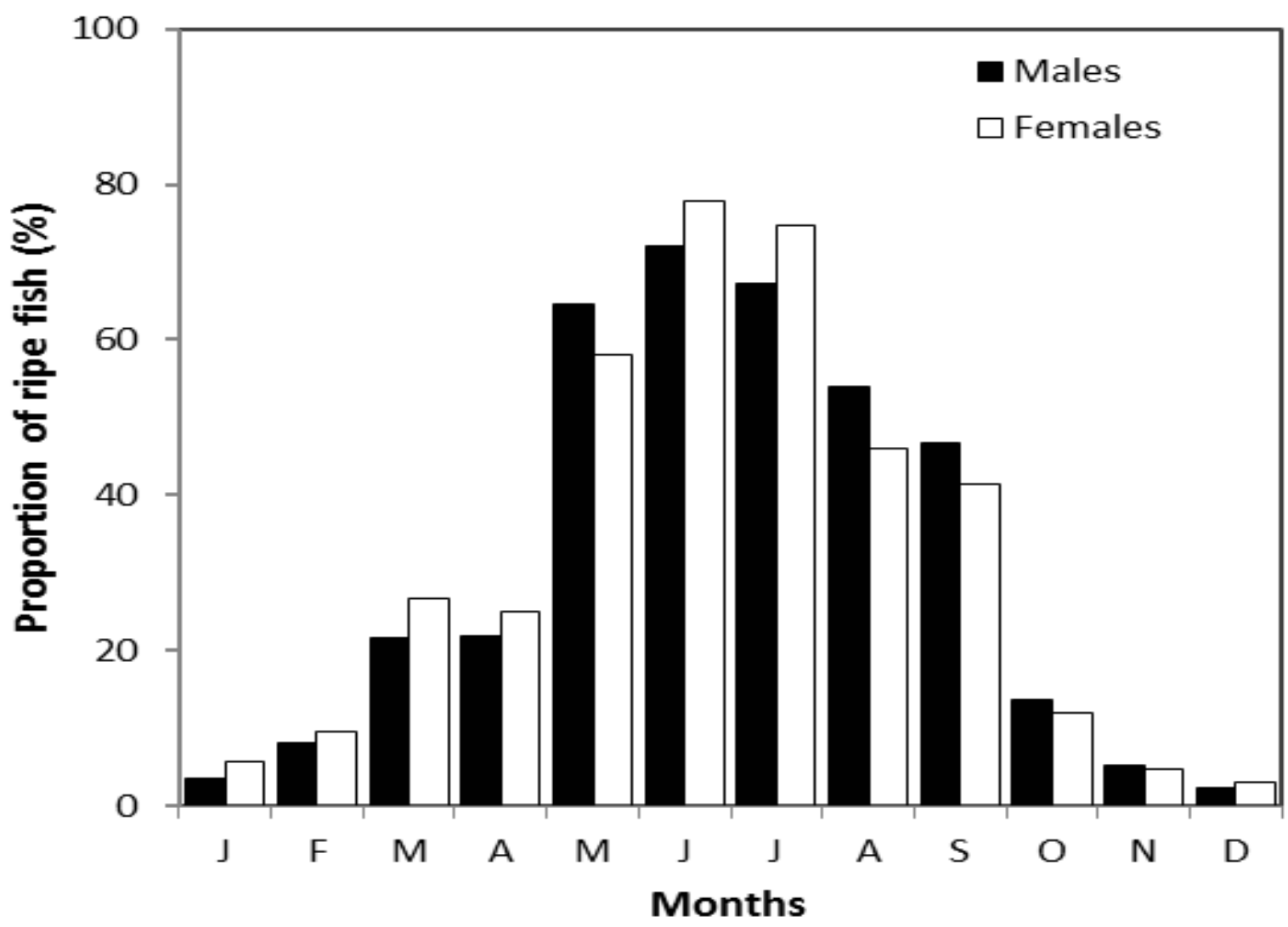

Figure 3. Breeding season of S. schall in Lake Chamo as indicated by the monthly proportion of ripe fish ( $\mathbf{\square -}$ males, $\square$ - females) during the sampling year.

Table 1. Number of males, females and the corresponding sex ratios (male: female) of S. schall from Lake Chamo. Samples were grouped in 4.9-cm size classes. Highly significant $* *,(P<0.01)$, very highly significant $* * *,(\mathrm{P}<0.001)$

\begin{tabular}{lcccc}
\hline Size class $(\mathrm{cm})$ & Males & Females & Sex ratio (M: F) & Chi-square \\
\hline $5.0-9.9$ & 1 & 2 & $1.0: 2.00$ & 0.33 \\
$10.0-14.9$ & 15 & 18 & $1.0: 1.20$ & 0.27 \\
$15.0-19.9$ & 35 & 53 & $1.0: 1.51$ & 3.68 \\
$20.0-24.9$ & 69 & 78 & $1.0: 1.13$ & 0.55 \\
$25.0-29.9$ & 20 & 25 & $1.0: 1.25$ & 0.56 \\
$30.0-34.9$ & 97 & 146 & $1.0: 1.51$ & $9.88^{* *}$ \\
$35.0-39.9$ & 40 & 85 & $1.0: 2.13$ & $16.20^{* * *}$ \\
\hline Total & 277 & 407 & $1.0: 1.47$ & $24.71^{* * *}$ \\
\hline
\end{tabular}


was $26.4 \mathrm{~cm}$ (Figure 4). The smallest mature male sampled was $16.7 \mathrm{~cm}$ and weighed $110.6 \mathrm{~g}$, while the smallest mature female captured was $17.8 \mathrm{~cm}$ and weighed $119.3 \mathrm{~g}$.

\section{Fecundity}

The weight of ripe gonads (preserved wet weight) ranged from $1.8 \mathrm{~g}-42.7 \mathrm{~g}$ with a mean of $11.4 \mathrm{~g}$. Fecundity ranged from 3,500-54,089 eggs with the mean of 21,017 eggs. The total and relative mean fecundity of $S$. schall was 21,017 eggs female ${ }^{-1}$ and

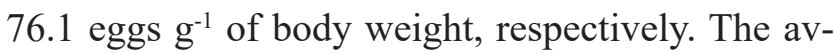
erage number of eggs $\mathrm{g}^{-1}$ of ovary (preserved wet weight) ranged from 983 to 3,797 with a mean of 1,847 eggs $\mathrm{g}^{-1}$.

The relationship between fecundity and fork length (Figure 5a) and fecundity and total weight (Figure $5 b$ ) were positive with low $\mathrm{R}^{2}$ values whereas the relationship between fecundity and ovary weight (Figure 5c) was positive and statistically significant. The best fit equations to the relationships, respectively were:

$$
\begin{aligned}
& \mathrm{F}= 1.635 \mathrm{FL}^{2.936}, \mathrm{R}^{2}=0.448, \mathrm{n}=43, \mathrm{p}<0.05 \\
&(\text { Figure 5a) } \\
& \mathrm{F}= 20.94 \mathrm{TW}^{1.225}, \mathrm{R}^{2}=0.420, \mathrm{n}=43, \\
& \mathrm{p}<0.05(\text { Figure } 5 \mathrm{~b}) \\
& \mathrm{F}=1,923 \mathrm{OW}+858.5, \mathrm{R}^{2}=0.905, \mathrm{n}=43, \\
& \mathrm{p}<0.01(\text { Figure 5c) }
\end{aligned}
$$

Table 2. Number of males and females and the corresponding sex ratios (male: female) of $S$. schall in different months of the year from Lake Chamo. Significant *, $(P<0.05)$, very highly significant $* * *,(P<0.005)$.

\begin{tabular}{lllll}
\hline Months & Males & Females & Sex ratio (M: F) & Chi-square \\
\hline January & 32 & 44 & $1: 1.38$ & 1.89 \\
February & 20 & 35 & $1: 1.75$ & $4.10^{*}$ \\
March & 11 & 17 & $1: 1.55$ & 1.29 \\
April & 15 & 22 & $1: 1.47$ & 1.32 \\
May & 19 & 27 & $1: 1.42$ & 1.39 \\
June & 31 & 29 & $1: 0.94$ & 0.07 \\
July & 15 & 27 & $1: 1.80$ & 3.43 \\
August & 48 & 62 & $1: 1.29$ & 1.78 \\
September & 18 & 29 & $1: 1.61$ & 2.57 \\
October & 20 & 41 & $1: 2.05$ & $7.23^{*}$ \\
November & 34 & 50 & $1: 1.47$ & 3.05 \\
December & 14 & 24 & $1: 1.71$ & 2.63 \\
\hline Total & 277 & 407 & $1: 1.47$ & $24.71^{* * *}$ \\
\hline
\end{tabular}




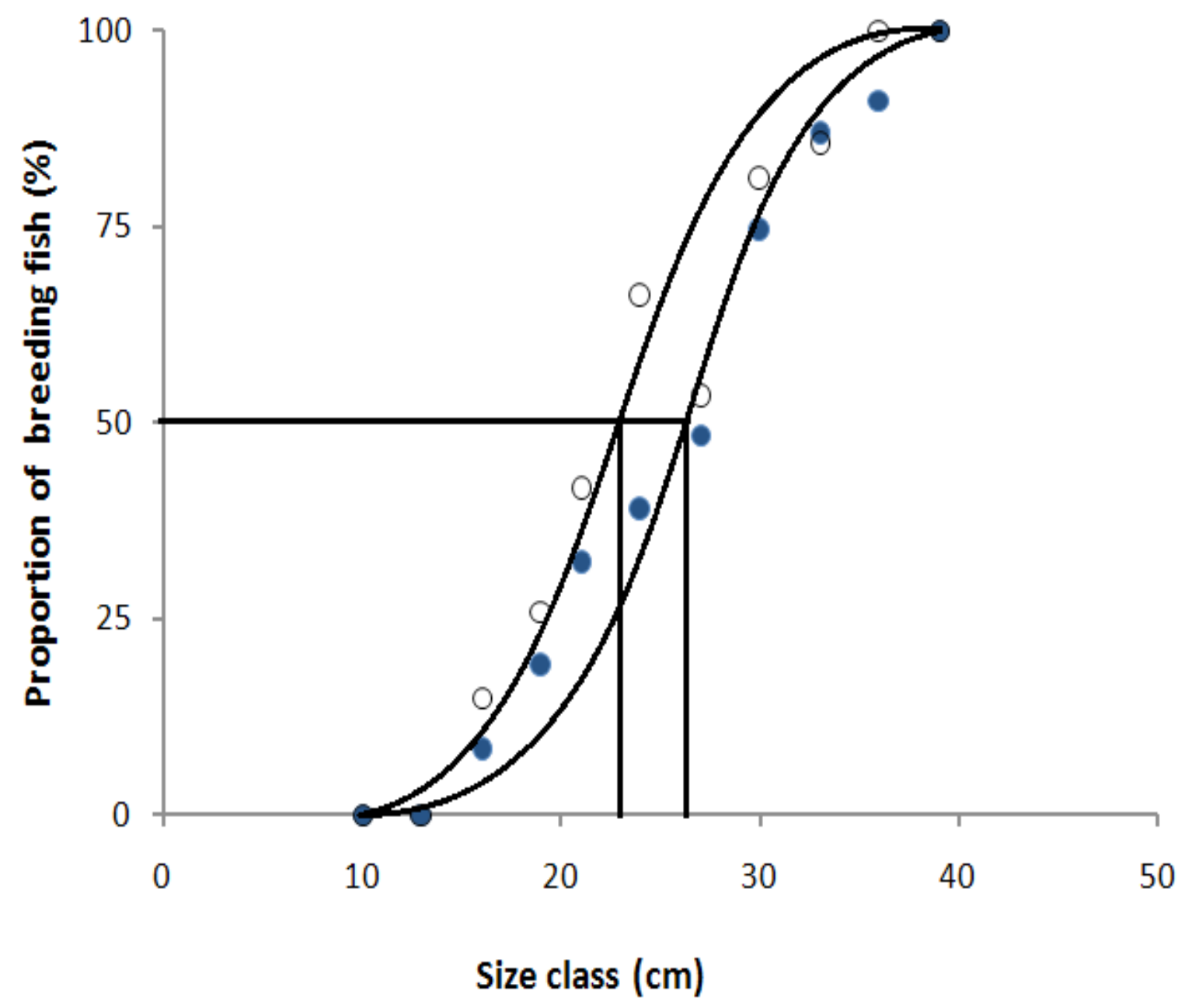

Figure 4. Length at first maturity for $S$. schall from Lake Chamo. Gonads at maturity stages III, IV and V (• - males), o -females). Data points $n=11$.

\section{DISCUSSION}

Length-weight regression coefficients (3.207 for males, 3.248 for females and 3.240 for the sexes combined) in this study shown considerable positive allometric growth pattern. Lalèyè et al. (2006) reported negative allometric growth pattern with regression coefficients of 2.832 for $S$. schall in Ouémé River (Bénin). Akombo et al. (2014) also found negative growth pattern (regression coefficients of 2.498 for males and 2.529 for females) in River Benue (Nigeria). Essien-Ibok et al. (2015) reported a regression coefficient value of 2.543 for the species in the lower Cross River, Akwa Ibom State (Nigeria). According to Froese (1998) the expected range of the exponent (b) of the length-weight relationship is between 2.5 and 3.5. When the specific gravity and the shape of a fish remain the same during its lifetime, its growth pattern is isometric and the value of length exponent would be 3 (Wootton, 1998). Unlike other studies that reported negative allometric growth pattern, S. Schall in Lake Chamo showed positive allometric growth pattern. Several factors are known to influence the length-weight relationship in fishes, including degree of stomach fullness, 

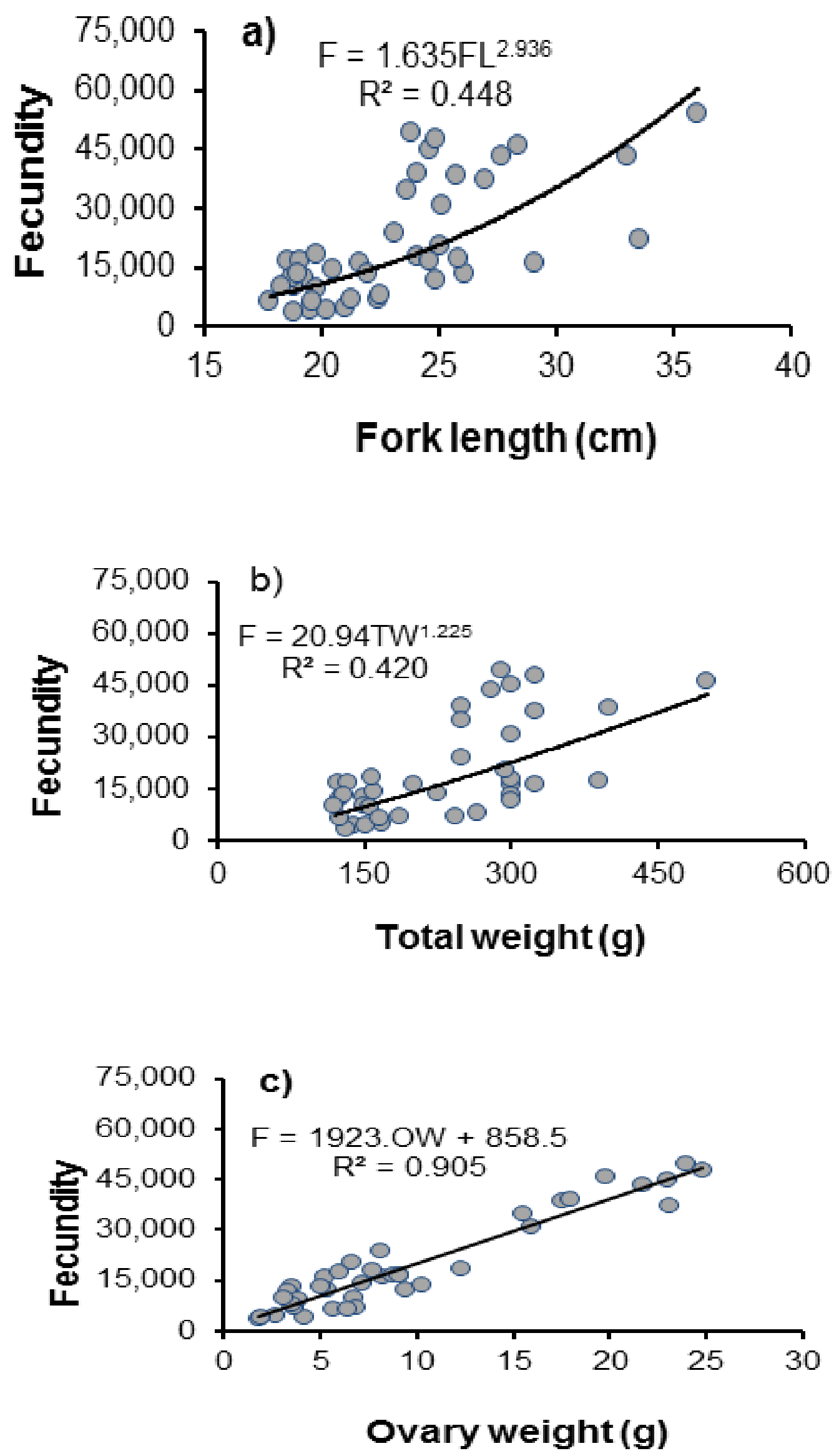

Figure 5. The relationship between fecundity and fork length (a), total weight (b) and ovary weight (c) of S. schall in Lake Chamo. 
gonad maturity, sex, size range, growth phase and condition of fish (Tesch, 1971). The observed difference in the value of length exponent in the present study and other geographical areas may be due to environmental differences, differences in utilized length ranges and/or differences in the number of specimen examined.

In Lake Chamo S. schall exhibited extended breeding season with intensive breeding activity occurring during the months of May to September (Figure 3). During the other months, even though a considerable proportion of fish were found with ripe gonads, their proportion was much lower than the main breeding season. In other African water bodies, S. schall was also found to have long spawning season from May to September in Ouémé River, Bénin(Lalèyè et al., 2006), mid-July to September (Blache, 1964), and July to September (Halim and Guma'a, 1989). Several environmental factors could be responsible for the high breeding activity of $S$. schall in Lake Chamo during the months of May to September. The major rainy season of the area falls within that period. High rainfall and subsequent rise in water level were implicated as the triggering factors for spawning of many fish species in different parts of Africa (Van der Waal, 1974; Willoughby and Tweddle, 1978; Tesfaye Wudneh, 1998; Elias Dadebo, 2000; Elias Dadebo et al., 2003; Lalèyè et al., 2006). The differences observed in the timing of reproduction in different parts of Africa could be due to the different environmental and climatic conditions in the habitats. Dadzie and Okach (1989) suggested that decline in water conductivity as a result of flooding could be a positive spawning stimulus in $B$. docmak in Lake Victoria. A fish should reproduce at that time of year that will tend to maximize its lifetime production of offspring. The larvae fish must hatch into a world that can provide appropriate food, pro- tection from predators and unfavorable abiotic conditions (Wootton, 1998).

The overall sex ratio of $S$. schall was significantly different from 1:1 in the present study. Females were numerically dominant in all size classes even though the differences were significant only in size classes above $30 \mathrm{~cm}$. Significantly more number of females was also caught in February and October. Variations in sex ratios have been attributed to differential growth or maturity rates, differential mortality rates, or differential migratory patterns between males and females (Sandovy and Shapiro, 1987; Matsuyama et al., 1988) or segregation of the sexes at different habitats (Hopson, 1972; 1982). Although the above phenomena were not observed in $S$. schall during the present study, segregation of the sexes was observed in the tiger fish (Hydrocynus forskahlii Cuvier), a piscivorous fish in Lake Chamo. From March to June more females were caught (male: female; 1:45) in shallow areas of the lake, whereas males predominantly made up the catch in early August with a sex ratio of 1:10 (female: male) was recorded (Elias Dadebo, 2002). The sizes at first maturity of $S$. schall in the present study (23.1 cm for males and $26.4 \mathrm{~cm}$ for females) (Figure 4) were smaller than those reported by Mekkawy and Hassan (2011) for the species in River Nile (Egypt) (29.4 cm SL for males and 28.2 $\mathrm{cm}$ SL for females). However, the values obtained in the present study were much larger than the values reported by several authors from different parts of Africa. Albaret (1982) obtained $15.5 \mathrm{~cm}$ of size at maturity for $S$. schall in Lagoon Ébrié (Ivory Coast). Halim and Guma'a (1989) estimated 14$15 \mathrm{~cm}$ SL in the White Nile near Khartoum.OforiDanson (1992) reported $20.0 \mathrm{~cm}$ TL for females in the Kpong Headpond (Ghana). Willoughby (1979) reported smaller sizes at maturity for $S$. schall (10.4 cm for males and $11.8 \mathrm{~cm}$ for females) 
in Lake Kanji (Nigeria). Size at maturity of fish may be affected by several physical and biological factors such as food availability, predation, and other abiotic factors (Wootton, 1998). The large discrepancy in the size of maturity of $S$. schall observed between the findings of the different authors could be due to the varying environmental conditions experienced. Size at maturity is also negatively correlated to the degree of fishing mortality. As mortality increases, fish populations respond to the new circumstances by changing their life-history pattern in order to compensate for the losses imposed by fishing activity (Garrod and Horwood, 1984; Wootton, 1998). In this connection, the relatively larger size at first sexual maturity of $S$. schall found in the present study could be because the species is not fished at all in Lake Chamo.

Fecundity of $S$. schall in Lake Chamo $(3,500-$ $54,089)$ varies greatly from counts given by other investigators in different African water bodies. Olatunde (1989) studying S. schall in Zaria, Nigeria has reported a low of 2,014- 13,262. Halim and Guma'a (1989) working on the same species have estimated fecundity count of 10,000-90,000 eggs from the White Nile near Khartoum. On the other hand Ofori-Danson (1992) has reported a high fecundity range of 14,000- 165,000 eggs for the species in Kpong Headpond, Ghana. Similarly, Nawar (1959) estimated fecundity of $S$. schall to be between 7,000- 130,000 eggs. In the present study fecundity increased in proportion to 2.936 power of length. Wootton (1979) reported $b$ values in the relationship of fecundity to length of 62 fish species to range between one and five, most values ranging from 3.25 to 3.75 . In comparison to fecundity of $S$. schall from other African water bodies, the values obtained in the present study are low.

\section{CONCLUSION}

Length and weight of $S$. schall were positively related and statistically significant. Both sexes exhibited positive allometric growth pattern. Intensive breeding activity was observed during the months of May to September which is almost coincident with the rainy season of the area. High rainfall and subsequent rise in water level may be responsible for triggering spawning of S. schall in Lake Chamo. A preponderance of females was evident in all size classes although the differences were significant only in size classes above $30 \mathrm{~cm}$. The sizes at first maturity in the present study $(23.1 \mathrm{~cm}$ for males and $26.4 \mathrm{~cm}$ for females) were among the highest values estimated for the species in different parts of Africa. Fecundity estimates of $S$. schall in Lake Chamo $(3,500-54,089)$ were generally low in comparison to other studies conducted in different inland water bodies of Africa.

\section{ACKNOWLEDGMENTS}

I am grateful to the Department of Biology, Hawassa University for providing laboratory facilities and logistic support for the field trips. This study was financially supported by the Norwegian Program for Development, Research and Higher Education (NUFU); Project ID: NUFU PRO 2007/10115.

\section{REFERENCES}

Albaret, J.J. (1982). Reproduction etfécondité des poisons d'eaudouce de Côte d'Ivoire. Revue d'Hydrobiologie Tropicale 15 (4): 347-371.

Akombo, P.M., Akange, E.T., Adikwu, I.A and Araoye, P.A. (2014). Length-weight relationship, condition factor and feeding habits of Synodontis schall (Bloch and Schneider, 1801) in River Benue 
at Makurdi, Nigeria. International Journal of Fisheries and Aquatic Studies 1(3): 42-48.

Amha Belay and Wood, R.B. (1982). Limnological aspects of an algal bloom on Lake Chamo in Gamo Goffa Administrative region of Ethiopia in 1978. SINET: Ethiopian Journal of Science 5: 1-29.

Bagenal, T.B and Braum, E. (1978). Eggs and early life history. In: Methods for Assessment of Fish Production in Freshwaters. IBP Handbook No. 3, pp. 165-201 (Bagenal, T., ed.). Blackwell Scientific Publications, London.

Beadle, L.C. (1981). The Inland Waters of Tropical Africa: An Introduction toTropical Limnology. $2^{\text {nd }}$ ed. Longmans, New York.

Blache, J. (1964). Les poissons du bassin du Tchadet du basin adjacent du May Kebbi. Etude systématiqueetbiologique. Paris. Cahiers Mémoires ORSTOM 4 (2): 1-485.

Dadzie, S and Okach, J.O. (1989). The reproductive biology of a siluroid catfish, Bagrus docmak (Cypriniformes: Bagridae) in the Winam Gulf of Lake Victoria. Journal of African Zoology 103:143-154.

Daget, J., Gosse, J.P and Teugel, G.G. (1991). Checklist of the Freshwater Fishes of Africa. (CLOFFA). Vol. 4. Orstom-Mirac, Paris.

Echeverria, T.W. (1987). Thirty-four species of California rockfishes: maturity and seasonality of reproduction. United States Fisheries Bulletin 85: 229-250.

Elias Dadabo (2000). Reproductive biology and feeding habits of the catfish Clarias gariepinus Burchell (Pisces: Clariidae) in Lake Hawassa, Ethiopia. SINET: Ethiopian Journal of Science 23: 231-246.

Elias Dadebo (2002). Reproductive biology and feeding habits of some fish species in Lake Chamo,
Ethiopia. Ph. D. Thesis, Addis Ababa University, Addis Ababa.

Elias Dadebo, Ahlgren, G and Ahlgren, I. (2003). Aspects of reproductive biology of Labeo horie Heckel (Pisces: Cyprinidae) in Lake Chamo, Ethiopia. African Journal of Ecology 41:31-38.

Elias Dadebo, Zinabu Gebre-Mariam and Ahlgren, G. (2012). Feeding habits of the catfish Synodontis schall (Bloch and Schneider) (Pisces: Mochokidae) with emphasis on its scale-eating habits in Lake Chamo, Ethiopia. Ethiopian Journal of Biological Sciences 11(2): 117-132.

Essien-Ibok, M.A., Ekpo, I.E and Bassey, H.E. (2015). Studies on the aspect of the biology of Mochokidae in the lower Cross River, Akwalbom State, Nigeria. Direct Research Journal of Agriculture and Food Science 3 (11): 193-205.

Frank, H andAlthoen, S.C. (1994). Statistics: Concepts and applications. Cambridge University Press, Cambridge.

Froese, R. (1998). Length-weight relationships for 18 less studied fish species. Journal of Applied Ichthyology 14: 117-118.

Garrod, D.J and Horwood, J.W. (1984). Reproductive strategies and the response to exploitation. In: Fish Reproduction, pp. 367384 (Potts, G.W. and Wootton, R.H., eds.) Academic Press, London.

Golubtsov, A.S., Darkov, A.A., Dgebuadze, Y.Y and Mina, M.V. (1995). An Artificial Key to Fish Species of Gambella Region. Joint EthioRussian Biological Expedition. Artistic Printing, Addis Ababa.

Golubtsov, A.S and Redeat Habteselassie (2010). Fish faunas of the Chamo-Abaya and Chew Bahir basins in southern portion of the Ethiopian Rift 
Valley: Origin and prospects for survival. Aquatic Ecosystem Health 15(1): 47-55.

Hailu Anja and Seyoum Mengistou (2001). Food and feeding habits of the catfish Bagrus docmak Forsskål (Pisces: Bagridae) in Lake Chamo, Ethiopia. SINET: Ethiopian Journal of Science 24: 239-254.

Halim, A.I.A and Guma'a, S.A. (1989). Some aspects of the reproductive biology of Synodontis schall (Bloch-Schneider, 1801) from the White Nile near Khartoum. Hydrobiologia 178: 243-251.

Holden, M.J and Raitt, D.F.S. (1974). Manual of fisheries science. Part 2. Methods of resource investigation and their application. FAO Fisheries Technical Paper No. 115, Rome.

Hopson, A.J. (1972). A study of the Nile perch (Lates niloticus (L.), (Pisces: Centropomidae) in Lake Chad. Overseas Research Publication No. 19. Overseas Development Administration, London.

Hopson, A.J. (1982). The biology of Lates niloticus (L.) in Lake Turkana. In: A Report on the Findings of the Lake Turkana Project 1972-75, pp. 12851299 (Hopson, A.J., ed.) Overseas Development Administration, London.

Lalèyè, P.A. Chikou, J.C. Philippart, G. Teugeuls and Vandewalle, P. (2006). Studies on the biology of two species of catfish Synodontis schall and Synodontis nigrita (Ostariophysi: Mochokidea) from the Ouémé River, Benin. Journal of Zoology 136 (2):193-201.

Lowe-McConnell, R.M. (1987). Ecological Studies in Tropical Fish Communities. Cambridge University Press, Cambridge.

Marquardt, D.W. (1963). An algorithm for least squares estimation of nonlinear parameters. Journal of the Society for Industrial and Applied Mathematics 11(2): 431-441.
Matsuyama, M., Adachi, S., Nagahama, Y and Matsuura, S. (1988). Diurnal rhythm of oocyte development and plasma steroid hormone levels in the female red sea bream during the spawning season. Aquaculture 73:357-372.

Mekkawy, I.A.A and Hassan, A.A. (2011). Some reproductive parameters of Synodontis schall (Bloch and Schneider, 1801) from the River Nile, Egypt. Journal of Fisheries and Aquatic Science 6: 456-471.

Mohr, P.A. (1962). The Ethiopian Rift System. Bulletin of Geophysical Observatory 3(1): 33-62.

Mulugeta Wakjira (2016). Fish diversity, community structure, feeding ecology and fisheries of lower Omo River and the Ethiopian part of Lake Turkana, East Africa. Ph. D. Thesis, Addis Ababa University, Addis Ababa.

Nawar, G. (1959). On the fecundity of the Nile catfish, Synodontis schall (Bloch-Schneider, 1801). Sudan Notes and Records 40: 139-140.

Ofori-Danson, P.K. (1992). Ecology of some species of catfish Synodontis (Pisces: Mochocidae) in the Kpong Headpond in Ghana. Environmental Biology of Fishes 35: 49-61.

Olatunde, A.A. (1989). Some aspects of the biology of Synodontis schall (Block-Schneider). Journal of Aquatic Science 3:49-54.

Paugy, D. and Roberts, T.R. (1992). Mochokidae, In: Faune des poisons de'eauxdoucesetsaumatresd'Afrique de 1'Ouest Tome 2, pp. 500-563(Paugy, C.D. and Teugels, G.G. eds.). Coll, Leveque, Faune Tropicale No. 28, Musee Royal de.

Reyntjens, D., Tarekegn Mengistu, Tesfaye Wudneh and Palin, C. (1998). Fisheries development in Ethiopia. Which way now? Mars Bulletin 11(1): 1-3. 
Sandovy, Y and Shapiro, D.Y. (1987). Criteria for the diagnosis of hermaphroditism in fishes. Copea 1:136-156.

Sanyanga, R.A. (1996). The inshore fish populations of Lake Kariba with reference to the biology of Synodontis zambezensis Peters, 1852. Ph.D. Thesis, Stockholm University, Stockholm.

Shibru Tedla (1973). Freshwater Fishes of Ethiopia. Haileselasse I University Press, Addis Ababa.

Snyder, D.E. (1983). Fish eggs and Larvae. In: Fisheries Techniques, pp. 165-197 (Nielsen, L. A. and Johnson, D. L., eds.). Southern Printing Company Inc., Blacksburg.

Tesch, W. (1971). Age and growth. In: Methods for assessment of fish production in fresh waters $2^{\text {nd }}$ ed., pp. 97-130 (Ricker, W.E. ed.). International Biological Programme. Oxford.

Tesfaye Wudneh (1998). Biology and management of fish stocks in Bahir Dar Gulf, Lake Tana, Ethiopia. Ph.D. Thesis, Wageningen Agricultural University, Wageningen.

Van der Waal, B.C.W. (1974). Observation on the breeding habits of Clarias gariepinus (Burchell). Journal of Fish Biology 6: 23-27.

Willoughby, N.G. (1974). The ecology of the genus Synodontis (Pisces: Siluriodei) in Lake Kanji, Nigeria. Ph. D. Thesis, University of Southampton, London.

Willoughby, N.G. (1979). Some aspects of the ecology of Synodontis (Pisces: Siluroidei) in Lake Kainji during its early years. In: Proceedings of the International Conference on Kainji Lake and River Basins Development in Africa, Vol. 2, pp.376-386,Kainji Lake Research Institute, Ibadan.
Willoughby, N.G and Tweddle, D. (1978). The ecology of the catfish Clarias gariepinus and Clarias ngamensis in the Shire Valley, Malawi. Journal of Zoology 186: 507-534.

Wootton, R.J. (1979). Energy costs of egg production and environmental determinants of fecundity in teleost fishes. Symposium of Zoological Society of London 44:133-159.

Wootton, R.J. (1998). Ecology of Teleost Fishes. Chapman and Hall, London. 